\title{
The efficacy of autobiographical memory specificity training (MEST) on post- traumatic stress symptoms in veterans with post-traumatic stress disorder
}

\author{
Rasool Moin Farsani ${ }^{1,2}$, Zohreh Ranjbar Kohan ${ }^{3}$ \\ 1-MA in Clinical Psychology, Department of Clinical Psychology, Islamic Azad University Isfahan \\ (Khorasgan) Branch, Isfahan, Iran. \\ 2- Mental Health Healthcare Center of Kiar, Community Health Center in Shalamzar, Chaharmahal and \\ Bakhtiari, Iran (Corresponding Author). $\quad$ E-mail: Hamdelan92@gmail.com \\ 3- Assistant Professor, Department of Clinical Psychology, Institute Amin, Isfahan (Foolad City), Iran.
}

Received: 14/08/2019

Accepted: 21/12/2019

\begin{abstract}
Introduction: One of the problem in patients with post-traumatic stress disorder is desire to recall the subject of trauma and also difficult in retrieval specified memories.

Aim: The aim of this study was to investigate the efficacy of autobiographical memory specificity training on post-traumatic stress symptoms in veterans with post-traumatic stress disorder in Isfahan.

Method: This study was a quasi-experimental with pre-test and post-test and follow up along with the control group. The population was hospitalized veterans in Rajaee hospital of Isfahan in 2017. 30 patients suffering from PTSD were selected through convenience sampling method and assigned randomly to two groups of experimental and control. The measure of study was post-traumatic stress disorder checklist (PCL). First, the pre-test was conducted in two groups, then experimental group $(n=15)$ was trained for 7 two- hours sessions in group according to autobiographical memory specificity training (MEST). After training post-test were taken from both groups. Data were analyzed by covariance method.
\end{abstract}

Results: The results showed that experimental group that have received autobiographical memory specificity training, have less post-traumatic stress symptoms than control group $(\mathrm{P}<0.05)$.

Conclusion: According to the results of the study, autobiographical memory specificity training(MEST) can be used as an important intervention in the prevention and treatment of post- traumatic stress symptoms along with current treatments.

Keywords: Specificity training, Autobiographical memory, Post-traumatic stress, Veterans

\footnotetext{
How to cite this article : Moin Farsani R, Ranjbar Kohan Z. The efficacy of autobiographical memory specificity training (MEST) on posttraumatic stress symptoms in veterans with post-traumatic stress disorder. Shenakht Journal of Psychology and Psychiatry. 2020; 6 (6): 113 124 .URL: http://shenakht.muk.ac.ir/article-1-608-fa.pdf
}

Copyright $\odot 2018$ the Author (s). Published by Kurdistan University of Medical Sciences. This is an open access article distributed under the terms of the Creative Commons Attribution-Non Commercial License 4.0 (CCBY-NC), where it is permissible to download, share, remix, transform, and buildup the work provided it is properly cited. The work cannot be used commercially without permission from the journal. 


\title{
اثربخشى آموزش اختصاصسازى حافظه سر كذشتى بر نشانهاى استرس بس از سانحه جانبازان مبتلا به اختلال استر س بـ إنساز سانحه
}

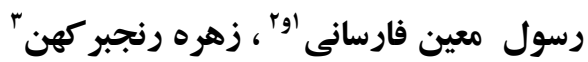 \\ ا.كارشناس ارشد روانشناسى بالينى، كروه روانشناسى بالينى، دانشكاه آزاد اسلامى واحد اصفهان (خوراسگان)، اصفهان، ايران.
}

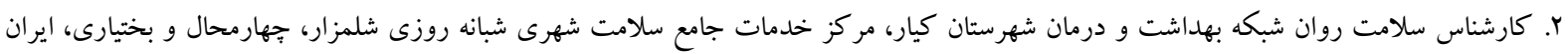

(مولف مسئول). ايميل: Hamdelan92@gmail.com ب. استاديار، كروه روانشناسى بالينى، موسسه عالى امين، اصفهان ( فولاد شهر)، ايران.

مقدمه: يكى از مشكلات افراد مبتلا به اختلال استرس پِ از سانحه، گرايش به يادآورى مواد مربوط به آسيب و مشكل در بازيابى وقايع اختصاصى است. هدف: هدف از يُزوهش حاضر، بررسى اثر بخشى آموزش اختصاص سازى حافظه سر گذشتى بر نشانه هاى استرس يس از سانحه در جانبازان مبتلا به اختلال استرس بس از سانحه شهر اصفهان بود.

روش: اين يزوهش يكك بثوهش نيمه تجربى و طرح آن از نوع بيش آزمون بس آزمون همراه با گروه كنترل بود. جامعه بثوهش جانبازان بسترى در بيمارستان شهيد رجايى شهر اصفهان در سال هوسا بود. از بين آن ها .ب نفر مبتلا به اختلال استرس ڤس از

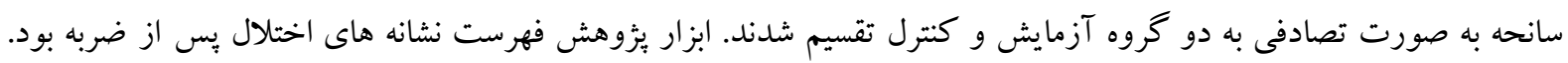

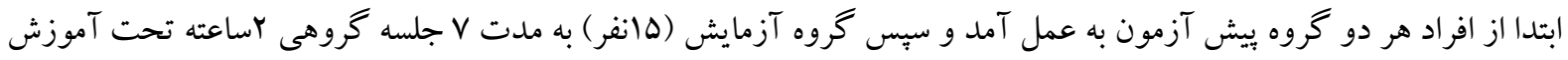

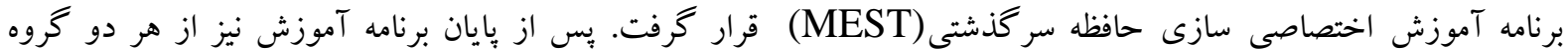

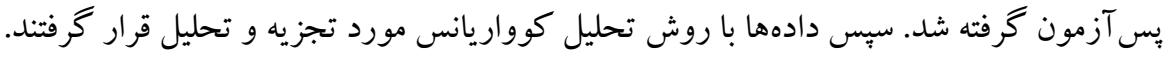
يافته ها: نتايج نشان داد كه در مقايسه با گروه كنترل، آموزش اختصاصى سازى حافظه موجب كاهش نشانه هاى اختلال استرس

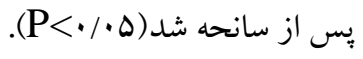
نتيجه كيرى: با توجه به نتايج يزوهش آموزش مبتى بر بهبود و اصلاح حافظه سر گذشتى مى تواند به عنوان مداخلهاى مهم در

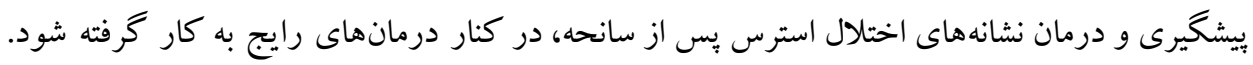
كليدوازهها: آموزش اختصاصسازى، حافظه سر گذشتى، استرس بِ از سانحه، جانبازان 


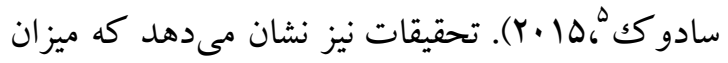

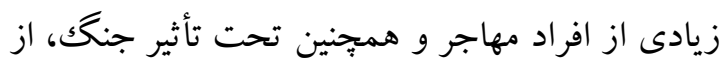
اختلال استرس بس از سانحه رنج مىبرند (مومارتين و

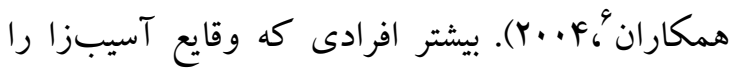

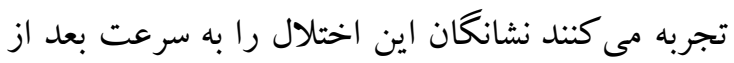

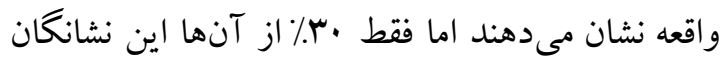
را تا يكك ماه بعد از واقعه دارا هستند (كوهن، بو كك

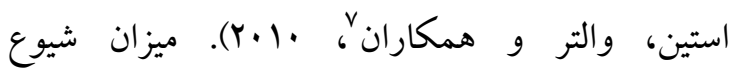

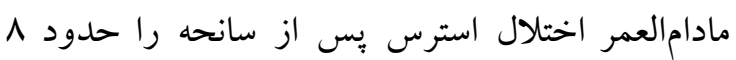
درصد جمعيت عمومى مىدانند و ميزان بروز آن در طول عمر 9 تا ها درصد تخمين زده مىشود كه البته علاوه بر اين رقم ه تا ها درصد ديخر از افراد نيز ممكن است دجار اشكال تحت بالينى اين اختلال باشند.

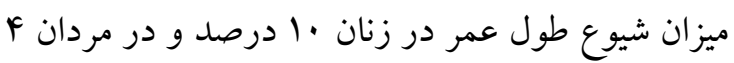
درصد است. همجنين ميزان شيوع بيمارىها همراه با اختلال استرس بس از سانحه زياد است، به شكلى كه

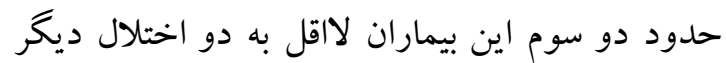

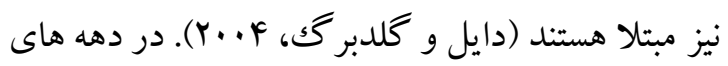
اخير در زمينهُ ابعاد شناختى اختلال استرس بِ از سانحه يزوهشهاى فراوانى شده است. گز ارشها در مورد ميزان و ماهيت تغييرات شناختى اين بيماران متفاوت و بسيار متنوع بوده و شامل دامنه وسيعى از نواقص شناختى كلى تا مشكلات اختصاصى حافظه

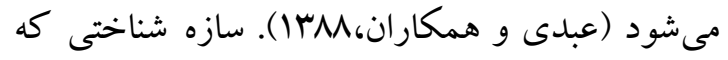
اخيراً توجه يزوهشخران را به خود هود جلب كرده است،

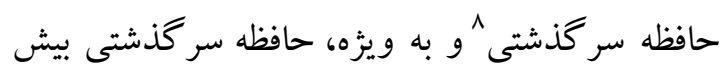

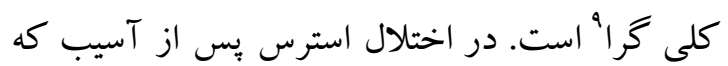

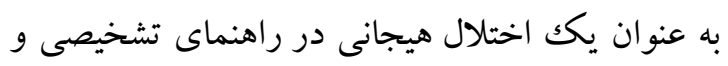

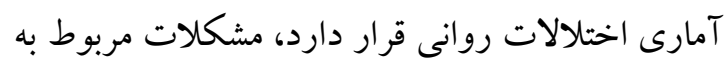

5- Sadock \& Sadock

6. Momartin \& et al

7. Kohen, Bookstein, Walter \& et al

8 - Autobiographical memory

9 - Overgeneral

\section{مقلدمه}

كشور ما در طول جنگك تحميلى بارها مورد حمله قرار گرفت و اين مسئله آسيبهاى جسمى و روانى بسيارى را بر جاى كذاشت، به طورى كه در جنگك

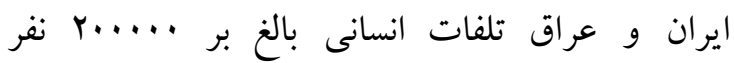
بر آورده شده است و حدود ....... نفر نيز در طول جنگك مجروح شدند (سادات و همكاران، وم/1). از آنجايى كه جنگك ايران و عراق ^ سال به طول انجاميد اين امر فشارها و آسيبهاى روان شناختى غير قابل

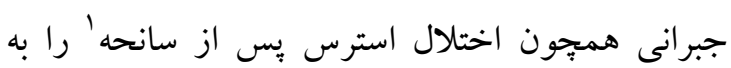
رزمندكان تحميل كرد. وقوع اين حوادث در سالهاى

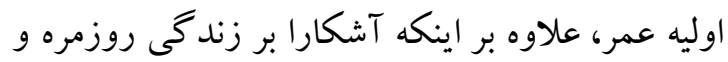
بهرهورى فرد مؤثر است، بر كيفيت زندكى ' شخص،

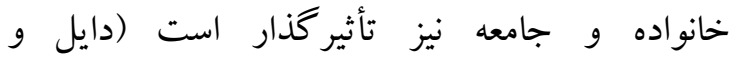

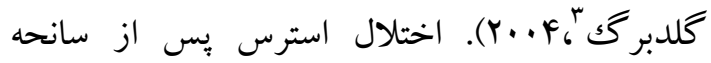
اختلالى است كه در آخرين ويرايش راهنماى تشخيصى و آمارى اختلالات روانشناسى ب تغييرات عمدهاى را نسبت به ويرايشهاى قبلى متحمل شده و در طبقه اى جديد به نام اختلالهاى ضربه هاى روانى

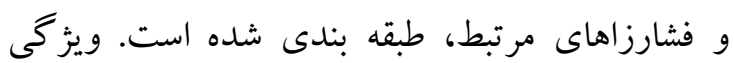

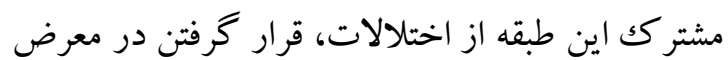
يكك رويداد آسيبزاست كه بايد صراحتاً به عنوان يكك معيار تشخيصى ذكر شود. در تعريف اين اختلال آورده شده است كه اختلال استرس بِ إس سانحه، اختلال شديدى در سلامت روان است كه به وسيلهى تجربهى مجدد و مداوم اجتناب، بيش انگيختكى و و نشانه هاى شناختى و عاطفى در بِاسخ مستقيم يا غيرمستقيم مو اجهشدن با محر كك هاى مربوط به حادثه

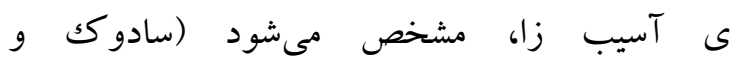

\footnotetext{
1- Post Traumatic Stress Disorder

${ }^{2}$ - Quality of Life

3. Diehl \& Goldberg

${ }^{4}$ - Diagnostic and Statistical Manual of Mental Disorders, Forth Edition,Third Revised(DSM-5)
} 
عبدى و همكاران (MMM) در يزوهش خود به اين نتيجه رسيدند كه افراد مبتلا به اختلال استرس بس از سانحه در مقايسه با گروه هاى كنترل قادر به بازيابى خاطرات اختصاصى كمترى هستند و كاهش اختصاصى بودن خاطرات در (AMT) با استرس پيس از سانحه كسترده ترى در گروه هاى داراى سابقه آسيب همراه است و همجنين افرادى كه داراى نشانه هاى شديدترى هستند، نواقص حافظه وسيعترى را نشان دادند (مومارتين و همكاران، F...... احدى و همكاران (rarI) در يُزوهشى نشان دادند كه افراد با اختلال استرس بِ از سانحه به طور معنادارى در عملكرد حافظهى شرح حال ضعيفتر از افراد عادى هستند در حالى كه در افسردگى و اضطراب تفاوت معنادارى بين دو گروه

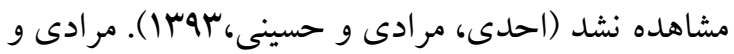

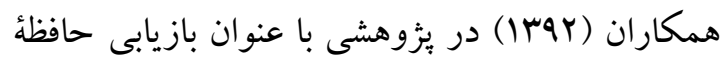
شرح حال، ارزيابى تجربه آسيب زا و تعريف خود در افراد مبتلا به اختلال تنيدگى پِ از سانحه، نشان دادند، افراد مبتلا به اين اختلال در مقايسه با گروه بهاه مقايسه، نشانه هاى افسردگى و اختلال بيشترى داشتند و خود -توصيفى ها و اهداف، بيشتر در بردارنده

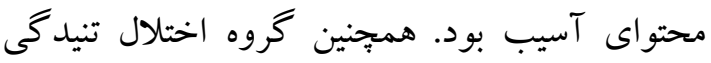
جس از سانحه، خاطرات اختصاصى كمترى را توليد كردند. علاوه بر اين، حجم و تعداد خاطرات توليد شده كم تر بود و سرانجام جهت گيرى خودمختار كمترى را در حافظهُ خود تعريفى و ساير مؤلفههاى حافظه شرح حال از خود نشان دادند. هم جنين، مرادى

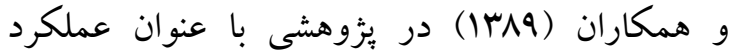
حافظه بيماران مبتلا به اختلال استرس پِ ور از سانحه

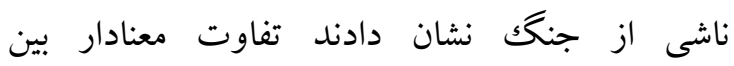
بازماند گان جنگك با اختلال استرس بس از سانحه، با دو

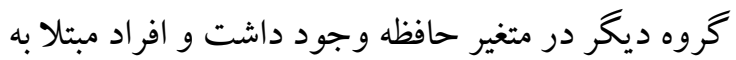
اختلال استرس پِس از سانحه از عملكرد ضعيف ترى
حافظه به ويزه حافظه شرح حال يكك نقش محورى در

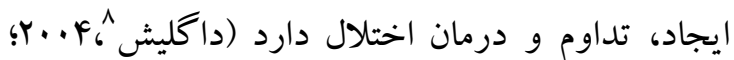
كان وى'، ه. …). حافظه شرح حال، نوع خاصى از حافظه رويدادى است كه داستان زندگى يا گذشتنهى شخصى فرد را شامل مىشود (لونتون و و

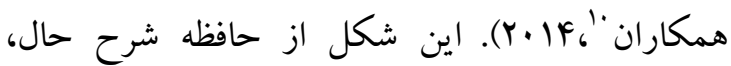

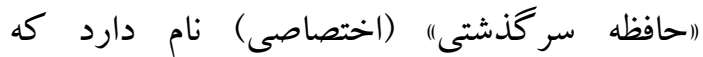
نظريهيردازان آن را به عنوان توانايى يادآورى

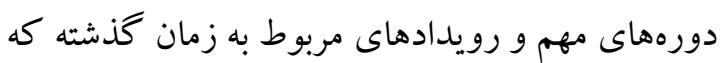
با (اخود) فرد در ارتباط هستند تعريف مى كنند. در حقيقت توانايى فرد در يادآورى جزئيات معنايى درباره كذشته شخصى خود است (جابسون و و

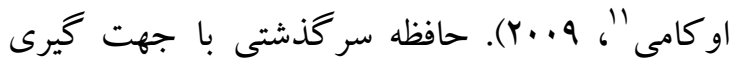
نسبت به دنيا، تصور آينده، اهداف شخصى و همجنين حل مسئله اجتماعى در ارتباط است (نلسون و

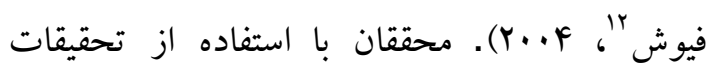
كسترده به اين نتيجه رسيدند كه بيماران مبتلا به اختلال استرس پِ از سانحه مشكلات عمده اى در

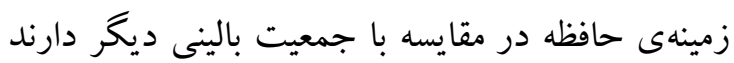

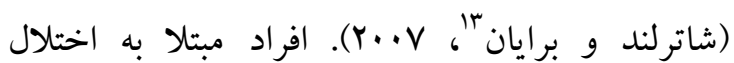
استرس بِ از سانحه گرايش به يادآورى بيشتر مواد

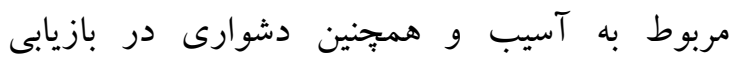
خاطرات شرح حال از وقايع خاص دارند (بو كلى و همكاران تحقيق طولى كه روى نوجو انان انجام شد نشان دادند،

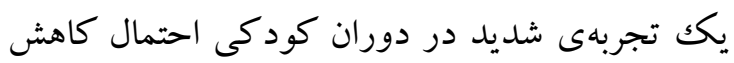
شديد در زمينهى حافظهى شرح حال در سن سر سالكى را افزايش مىدهد (كرين و همكاران،YF) F).

\footnotetext{
8 - Dalgleish

9. Conway

10 - Leventon \& et al

11- Jabson \& Okami

12 - Nelson \& Fivush

13 - Shutherland \& Bryant

${ }^{14}$ - Buckely \& et al

8 - Crane \& et all
} 
شد و سبِ با مراجعه به مركز نخهدارى جانبازان و بررسى يُونده هاى افرادى كه توسط همكاران روانشناس و وروان ورئشك معاينه شده و د داراى ملاككهاى تشخيصى استرس بس از سانحه ناشى از

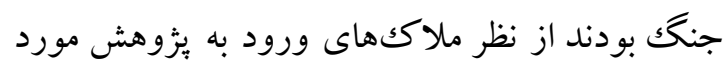

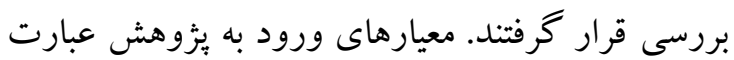

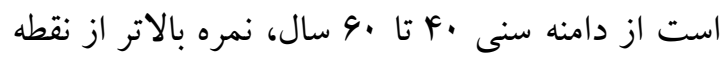

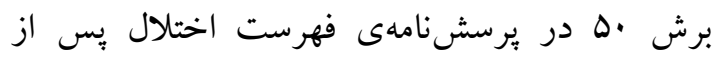
ضربه، داشتن حداقل مدرك سوم راهنمايى، رضايت آكاهانه جهت شركت در يثوهش و معيارهاى خروج نيز شامل ابتلا به بيمارى شديد جسمى، داشتن بيمارى فعال سايكوتيك،، عقب ماندگى ذهنى، رفتارهاى فعال

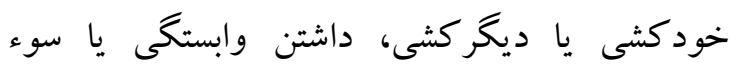
مصرف مواد مخدر حداقل در سه ماه گذشته. به دليل احتمال ريزش افراد در فرايند گروه، تعداد نمونه مورد مود

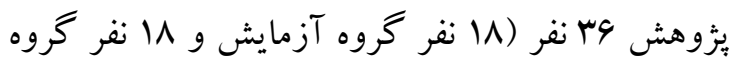

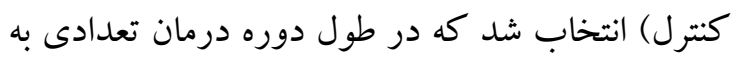
علت مرخص شدن از بيمارستان و همجينين برخى ديخر به دليل عدم تمايل به ادامه درمان، از گرووه خارج شدند. در نهايت تعداد ·r نفر (ها نفر آزمايش و ها

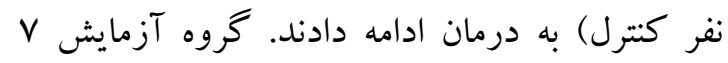
جلسه (Y جلسه در هفته و هر جلسه Y ساعت بود) مداخلهى حافظه سر گذشتى دريافت كردند و گرووه كنترل به درمان رايج خود بدون هيج مداخله ایى ادامه دادند (فقط داروهايى كه توسط روان بيزشك تجويز شده بود را مصرف كردند). در انتهاى جلسه هفتم از هر دو گروه يس آزمون به عمل آمد و ا ماه يس از

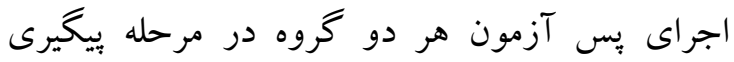
مورد ارزيابى مجدد قرار گرفتند. نكته ديخر اينكه

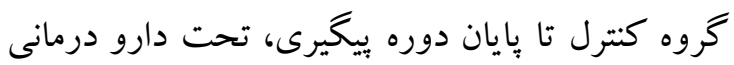
بود و مداخلات روانشناختى دريافت نكرد و بنا به رعايت اصول اخلاقى، هفت جلسه آموزش اختصاص دورداص
برخوردار بودند (مرادى، سليمى و فتحى آشتيانى،

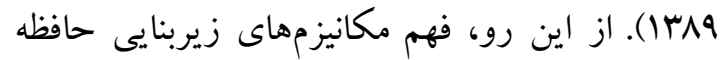
بيش كلى گرا از سويى و نيز آزمون تأثير مداخله هاى

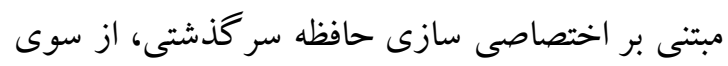
ديخر، به عنوان اهداف بزووهشى مهمى تلقى مى خردند كه هم به لحاظ نظرى و هم به لحاظ عملى و بالينى بسيار مفيد خواهند بود و اكنون زمان آن فرا رسيده

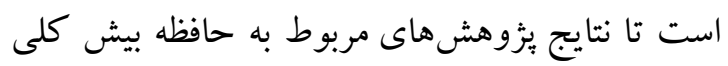

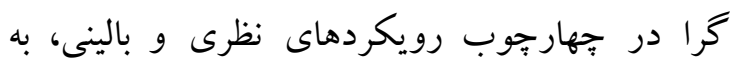
خصوص به دليل ارتباط آن با خاطره ها و حوادث منفى

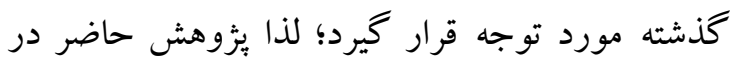

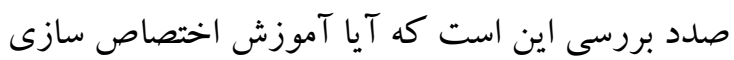

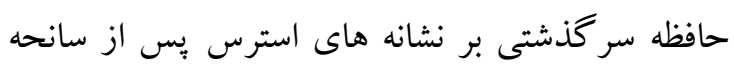

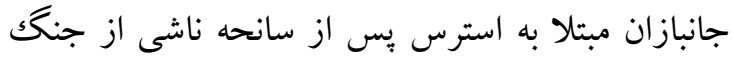

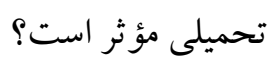

روش يثوهش حاضر از نوع نيمه تجربى و طرح آن از

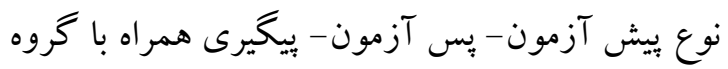
كنترل بود. جامعهى آمارى اين بيزوهش شامل كليه

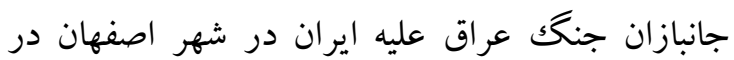
سال هوسا بود كه تشخيص اختلال استرس بِ از سانحه دريافت كرده بودند. با عنايت به اينكه طرح يثوهش حاضر نيمه تجربى بود و با توجه به اينكه حجم نمونه در اين نوع طرح ها، ها نفر در هر گروه آزمايش و گواه توصيه مى شود (دلاور، ولمبا)، نمونه مورد نياز براى اين يثزوهش شامل ·r نفر جانباز مرد بود. در اين يُوهش از روش در دسترس كه احتمال دست يابى به جانبازان مبتلا به نشانه هاى استرس بس از سانحه بيشتر بود، انتخاب شدند. ابتدا با مطالعه و ترجمه متون و بكري

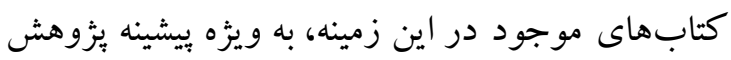
هاى موجود، ساختار و مفاد جلسه هاى درمانى آماده 
فهرست بازبينى اختلال استرس بِ از سانحه و مقياس

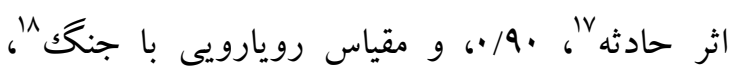
4 4 •، كزارش نمودند. علاوه بر آن نقطه برش •ه را براى اين مقياس به عنوان نقطه بهينه براى بيش بينى

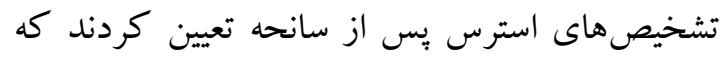

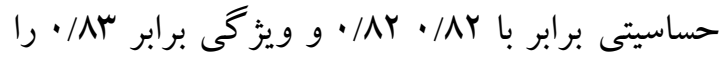
نشان داد. در يثزوهش حاضر ضريب آلفاى كرونباخ براى فهرست اختلال يس از ضربه ז^// محاسبه شد. بروتكل درمانى مورد استفاده در اين يزوهش نسخه

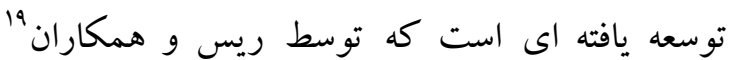

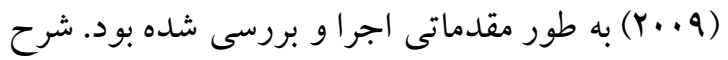
جلسات درمان مبتنى بر آموزش اختصاصى سازى حافظه سر گذشتى در جدول شماره ا بيان شده است.

17- Impact of event scale

${ }^{18}$ - Combat Exposure Scale

${ }^{19}$ - Raes \& et all
سازى حافظه سر گذشتى نيز بعد از اتمام يُوهش براى

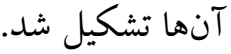
بعد از يايان مداخلات آموزشى و جمع آورى داده هاى

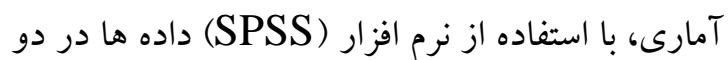
سطح توصيفى و استنباطى مورد تجزيه و تحليل قرار

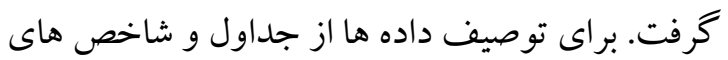
آمار توصيفى مثل ميانگين، انحراف معيار و براى استنباط آمارى داده ها، تحليل كوواريانس محاسبه كرديد.

ابزار فهرست اختلال بِ از ضربه هإ: اختلال بِ از ضربه

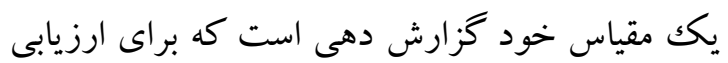
ميزان اختلال و غربال كردن اين بيماران از افراد عادى و ساير بيماران به عنوان يكك ابزار كمكك تشخيصى به كار مىرود. اين فهرست به وسيله ويترز و همكاران 19 (1994) بر اساس معيارهاى تشخيصى براى مركز ملى

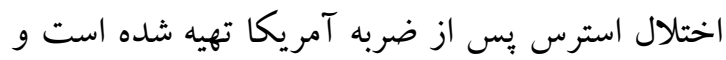
شامل IV ماده است كه ه ماده آن مربوط به علائم و نشانه هاى تجربه مجدد حادثه آسيب زا، V ماده آن مربوط به علائم و نشانه هاى كرختى عاطفى و اجتناب و ه ماده مربوط به علائم و نشانهاى برانگيختخى ورئى شديد است. روش نمره گذارى به صورت ليكرت

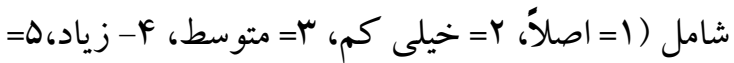
خيلى زياد) به دست مى آيد و در دامنه (V) (Vه) قرار

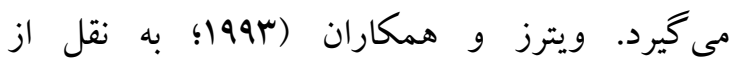

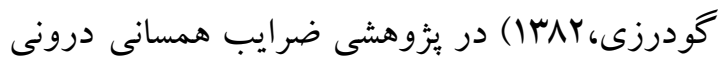
9V/• را براى كل مقياس و ضريب 99/• را به عنوان ضريب باز آزمايى به فاصله دو يا سه روز گزارش

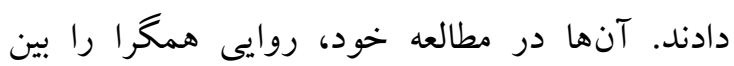

\footnotetext{
15 - Post-traumatic stress disorder checklist ${ }^{16}$ - Weathers \& et al
} 
جدول شماره ا ساختار جلسات برنامه آموزش اختصاصى سازى حافظه و شرح محتواى جلسات

\begin{tabular}{|c|c|}
\hline شرح جلسات & جلسات \\
\hline 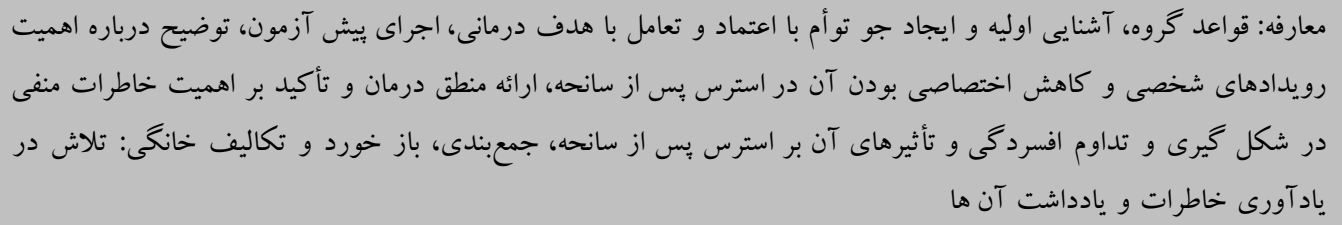 & جلسه اول \\
\hline
\end{tabular}

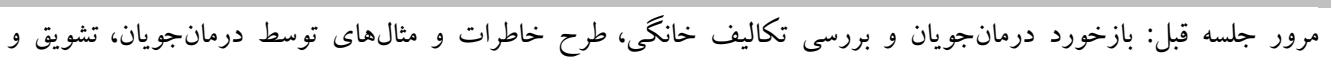

جلسه دوم

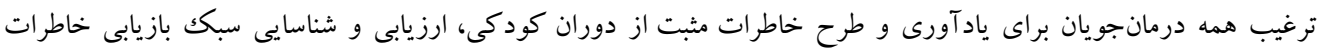

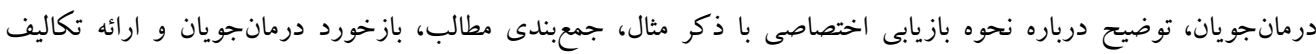

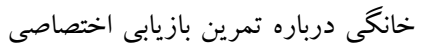

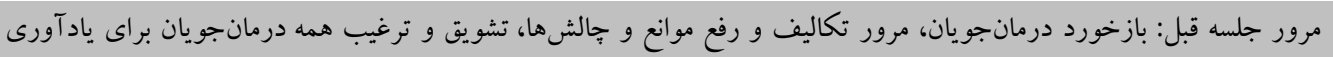

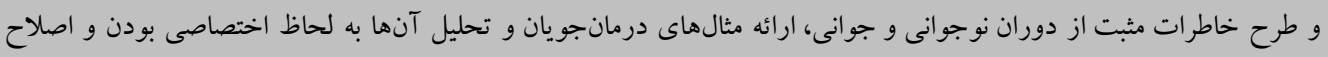

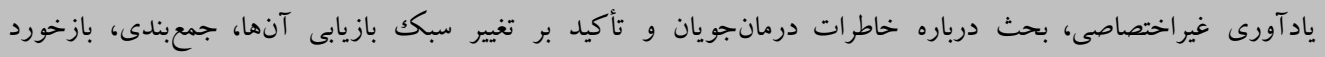

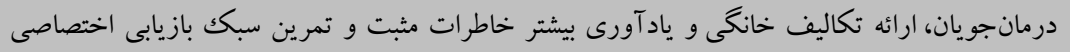

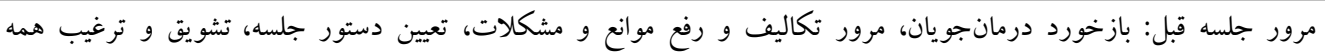

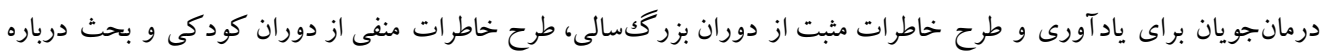

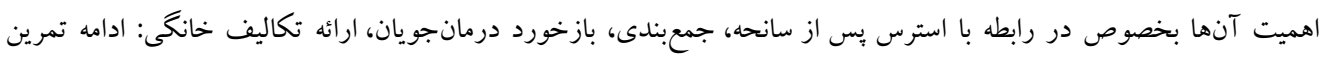

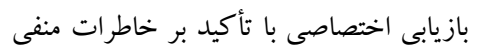

مرور جلسه قبل، دريافت بازخورد درمانجويان، مرور تكاليف، تعيين دستور جلسه، طرح خاطرات منفى از دوران نوجوانى و

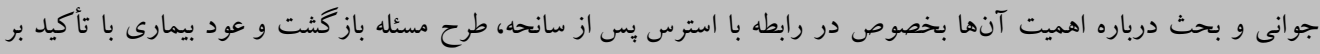

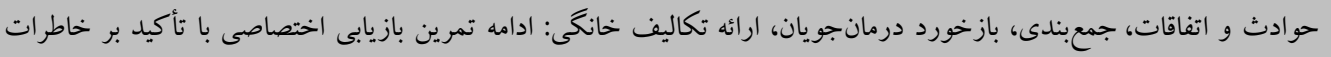
منفى

جلسه ششم مرور جلسه قبل، دريافت بازخورد درمانجويان، مرور تكاليف، طرح خاطرات منفى از دوران بزرگكسالى و بحث درباره اهميت

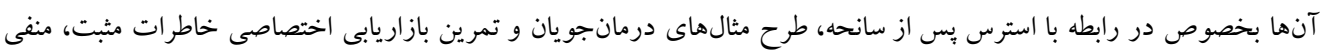

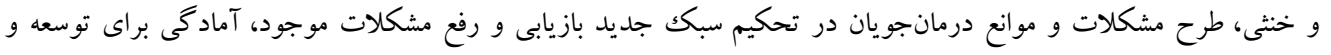

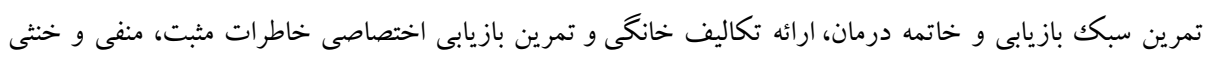

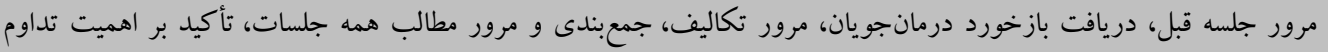
جلسه هفتم

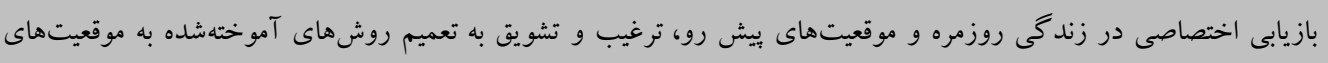

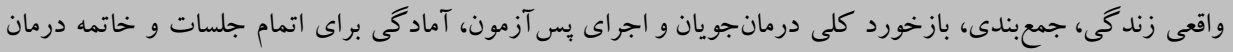

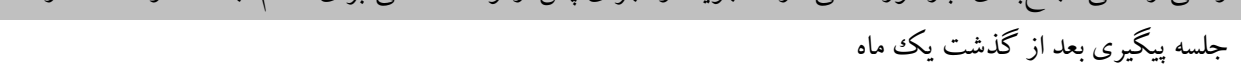

\section{يافتهها}

نفر فوق ليسانس بودند. شاخص هاى ميانگين و انحر اف معيار نمرات نشانهاى استرس بس از سانحه در مراحل بيش آزمون، بِ بـ آزمون و بيخيرى براى دو كروه آزمايش و كنترل در جدول شماره Y ارائه شده است. در جدول شماره بو \& نتايج تحليل كوواريانس تأثير عضويت گروهى بر نمرات بس آزمون و بيخيرى نشانه

$$
\text { هاى استرس بس از سانحه آمده است. }
$$

يافتهاى توصيفى و جمعيت شناختى به طور خلاصه عبارت بودند از: ميانگين سنى FA سال در گروه آزمايش و اه ال سال در كروه كنترل، همهى شركت كنند كان در هر دو كروه آزمايش و كنترل متأهل و در كروه آزمايش \& نفر زير دييلم، F نفر دييلم، 4 نفر ليسانس و ا نفر فوقليسانس، و همجنين در كروه كنترل ه نفر زير ديّلم، \& نفر ديبلم، ه نفر ليسانس و 1 
در جدول شماره Y شاخصهاى ميانگين و انحراف بيگيرى براى دو گروه آزمايش و كنترل ارائه شده

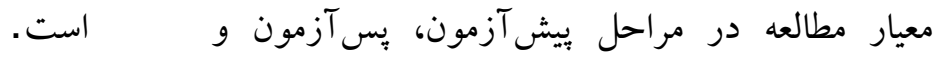

\begin{tabular}{|c|c|c|c|}
\hline \multicolumn{2}{|c|}{ استرس يِ از سانحه } & \multirow{2}{*}{ متغيرهاى وابسته } & \multirow[t]{2}{*}{ كروه } \\
\hline انحراف معيار & ميانكين & & \\
\hline F/qr & $94 / 99$ & ييش آزمون & \multirow{3}{*}{$\begin{array}{l}\text { آزمايش } \\
N=1\end{array}$} \\
\hline$r / \Delta 9$ & $\Delta \Delta / \Lambda$. & يس آزمون & \\
\hline$r / 4 \Lambda$ & $\Delta V / A$. & ييعيرى & \\
\hline$r / I V$ & $9 \% / . \cdot$ & ييش آزمون & \multirow{3}{*}{$\begin{array}{l}\text { كواه } \\
N=10\end{array}$} \\
\hline$r / 99$ & $9 . / 14$ & يس آزمون & \\
\hline$r / 19$ & $91 / 9$. & بيغيرى & \\
\hline
\end{tabular}

ابتدا نتايج ييش فرض هاى تحليل كوواريانس ارائه مى گردد. بررسى بيش فرض نرمال بودن با استفاده از آزمون شاييرو ويلكك در جدول ب آمده است.

\begin{tabular}{|c|c|c|c|}
\hline سطح معنادارى & درجه آزادى & شاخص آمارى & كروه \\
\hline.$/ 01$ & $r$. &.$/ 999$ & آزمايش \\
\hline$\cdot / A T$ & $r$. & . & كتترل \\
\hline
\end{tabular}

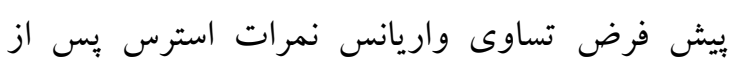

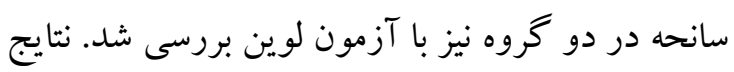
در جدول F آمده است.
طبق نتايج آزمون شاييرو - ويلك فرض مبنى بر اينكه تفاوت بين توزيع نمرات نمونه و توزيع بهنجار جامعه صفر است رد نمى شود.
سانحه در گروه آموزش اختصاص سازى را نشان مىدهد. در اين تحليل عضويت گروهى بهعنوان متغورو آنير

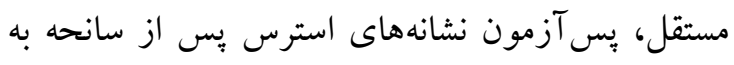

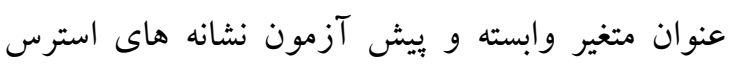
يس از سانحه به عنوان متغير كنترل تحليل شدند.
نتايج آزمون لوين، تساوى واريانس نمرات گرووه ها در مورد متغير نشانه هاى استرس بس از سانحه را تائيد نمود. جدول شماره ه نتايج تحليل كوواريانس تأثير عضويت كروهى بر نمرات پِ آزمون نشانهاى استرس يس از 


\begin{tabular}{|c|c|c|c|c|c|c|c|}
\hline توان & اندازه اثر & معنادارى & ضريبF & مجذورات مينكين & مجذورات & آدادى & شاخص آمارى \\
\hline
\end{tabular}

\begin{tabular}{|c|c|c|c|c|c|c|c|}
\hline $1 / \cdot \cdot$ & $\cdot / \Delta A$ & $1 \ldots$ & MN/DIF & rN/DIF & $194 / 91 \mu$ & 1 & استرس پيس آزمون نشانهاى سانحه \\
\hline \multirow[t]{3}{*}{$1 / \cdot \cdot$} & $\cdot / \Delta 9$ & $1 \cdots$ & $r q / r r r$ & $r q / r v r$ & $19 N / T \Delta 9$ & 1 & عضويت كروهى \\
\hline & & & & & $F / Y V G$ & rV & خطا \\
\hline & & & & & & $r$. & كل \\
\hline
\end{tabular}

فردى در نمرات نشانه هاى استرس يس از سانحه مربوط به تفاوت بين گرووه ها (درمان و عدم درم درمان) است. بررسى توان آمارى نيز حاكى از كفايت حجم نمونه در آزمون فرضيه است.

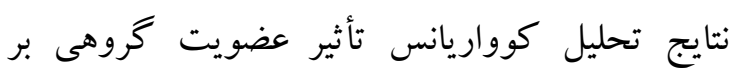
نشانهاى استرس يس از سانحه در مرحله بيخيرى نيز در جدول شماره 9 نشان داده شده است.
همان طور كه نتايج جدول شماره ه نشان مىدهد، بين نمرات نشانه هاى استرس پِ يس از سانحه در پس آزمون تفاوت معنادار وجود دارد ( ( p=/p). لذا فرضيه اصلى در مورد تفاوت بين ميانگين نمرات نشانه هاى استرس بس از سانحه تائيد شد (ه •/•> اندازه اثر (ضريب اتا=هه/•) نيز نشان مى دهد كه تهر ميزان اثر درمان بر نشانه هاى استرس يس از سانحه

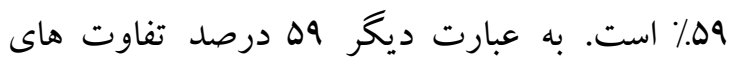

جدول شماره 9 نتايج تحليل كوواريانس تأثير عضويت تروهى بر نشانههاى استرس بِ از سانحه در مرحله بيَكيرى

شاخص آمارى

\begin{tabular}{|c|c|c|c|c|c|c|c|}
\hline $1 / \cdot$ & $\cdot / \Delta \Lambda$ & $1 \cdots$ & $r V / 9 \Delta$. & IrV/AQF & ITV/AQF & 1 & بيش آزترس هي از نشانه هاى \\
\hline $1 / \cdot$ & $\cdot / \Delta V$ & $1 \cdots$ & $r \Delta / q \cdot v$ & $\mid r \cdot / q V$. & $\mid r \cdot / q v$. & 1 & عضويت كروهى \\
\hline & & & & $91 / 1.9$ & $91 / 1.9$ & rV & خطا \\
\hline
\end{tabular}

در مرحله بيخيرى، هV درصد است. به عبارت ديخر ه درصد از تفاوت هاى فردى در نمرات نشانه هاى

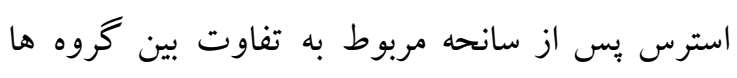

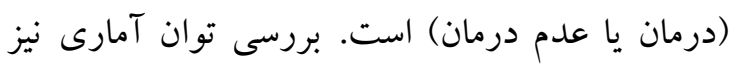
حاكى از كفايت حجم نمونه در آزمون فرضيه است.

\section{بحث}

فرضيه اصلى درباره تفاوت نمرات يّ آزمون نشانه هاى استرس يس از سانحه گرووه هاى آزمايش و كنترل
همان طور كه نتايج جدول شماره 9 نشان مىدهد، بين نمرات نشانههاى استرس پِ هـ از سانحه در مرحله

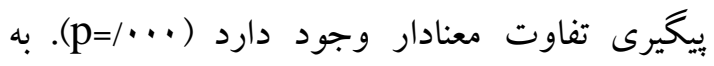

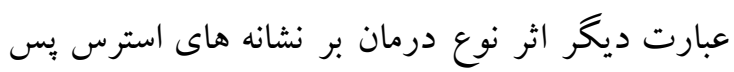

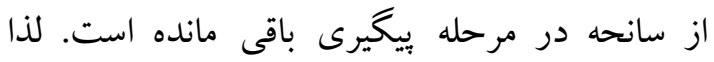
فرضيه اصلى در مورد تفاوت بين ميانكين نمرات نشانه هاى استرس بِ إس سانحه تائيد شد. بررسى

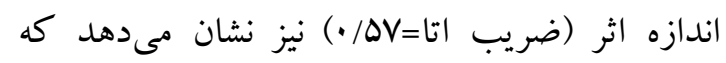
ميزان اثر نوع درمان بر نشانه هاى استرس بس از سانحه 
دوران كذشته افراد اتفاق افتاده است. نتيجه به دست Tمده از اين تحقيق با تحقيقات كراهام و همكاران

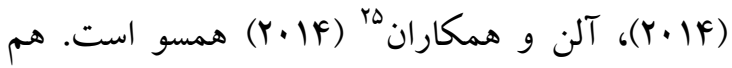

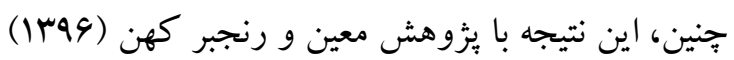
كه نشان داد آموزش اختصاصى سازى بر بر كاهش نشانهاى افسردگى جانبازان مبتلا به اختلال يس از سانحه مؤثر است، هم سو و هماهنگك است. كرين و

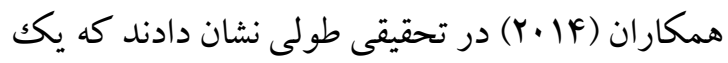
تجربهى شديد در دوران كودكى احتمال كاهش شديد در سن rا سالكى را در زمينهى حافظهى شرح حال افزايش مىدهد. مرادى و همكاران (rarا) در يثوهش خود با عنوان بازيابى حافظهُ شرح حال، ارزيابى تجربه آسيب و تعريف خود در افراد مبتلا به اختلال تنيدگى پِ إن از سانحه نشان دادند كه افراد مبتلا به اين اختلال خاطرات اختصاصى كمترى را توليد كردند و حجم و تعداد خاطرات توليد شده كم بود. عبدى و همكاران (INMA) عملكرد افراد مبتلا به اختلال استرس بس از سانحه ناشى از جنگك در حافظه شرح حال رويدادى را بررسى كردند. نتايج نشان داد كه افراد مبتلا به اختلال استرس يّ از سانحه در مقايسه با گروه هاى كنترل قادر به بازيابى خاطرات اختصاصى كمترى بودند، كاهش اختصاصى بودن

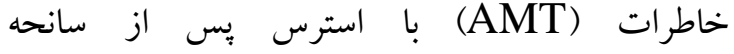
گستردهترى در گروههاى داراى سابقه آسيب همراه است و همجنين افرادى كه داراى نشانهاى شديدترى بودند، نو اقص حافظه وسيع ترى را نشان دادند. سرانجام، نتايج نشان داد كه ميزان اين نواقص با نشانهاى خاص استرس پِ از سانحه رابطه مستقيمى دارد. حاج محمدى و نشاط دوست (94) در ئزوهشى نشان دادند كه بيش كلى گرايى و كاهش اختصاص سازى

5 - Graham \& et all

6- Allen \& et all
در جانبازان مبتلا به اختلال استرس بِ از سانحه تائيد شد (جدوله). در واقع، نتايج نشان داد كه آموزش اختصاصى سازى در كاهش نشانه هاى استرس بِ از

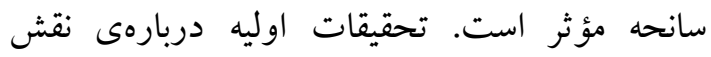

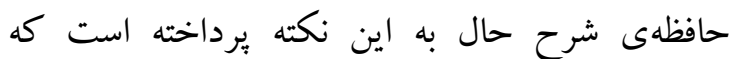
حافظه ممكن است بهواسطهى حالت خلقى كنونى دجار سو گيرى شود. در مورد نقص در حافظهى شرح حال، دو فرضيه براى تبين وجود دارد، اول اينكه،

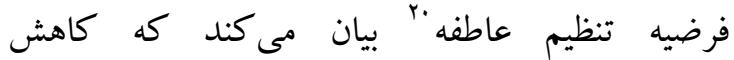
اختصاصى بودن حافظه، بيانكر يك راهبرد شناختى براى ممانعت از دسترسى به جزييات حوادث شرح حال رنج آور مانند تجربه آسيب زاست (ويليامز و همكاران استرسزاى بسيارى اتفاق مىافتد كه آنان با استفاده از يكك راهبرد شناختى، حوادث را به صورت كلى و و غير اختصاصى به خاطر مى آوردند تا به نحوى بتواند از اثرات منفى اين حوادث در زندكى شان بكاهن بهاند

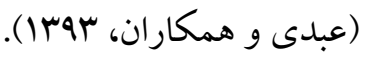

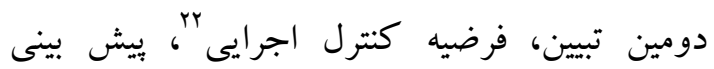
كنندهى عملكرد ضعيفتر در تكاليف شناختى است كه مستلزم تلاش است. اين فرضيه بيان مى كند كه كاهش يافتكى اختصاصى بودن حافظه در نمونه هاى داراى اختلال هيجانى، به عنوان نمونه اي از عملكرد ضعيف در تكاليف شناختى، ناشى از كنترل اجرايى

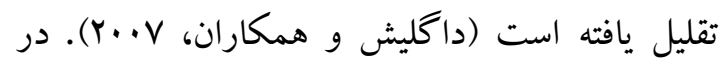
همين راستا تحقيق سامنر و همكاران داد كه بيش كلى گرايى در حافظهى شرح حال افراد مبتلا به اختلال استرس وبس از سانحه ناشى از اجتناب آنان از اثرات منفى حوادث مصيبت بارى است كه در بهر

\footnotetext{
${ }^{20}$ - Affect Regulation

2. Williams \& et al

22 - Executive control

23 - Sumner \& et al
} 
در يايان از مساعدتهاى تمامى عوامل محترم بنياد شهيد اصفهان و تمامى جانبازان عزيزى كه بى دريغ در روند اين يزوهش ما را يارى نمودند، صميمانه

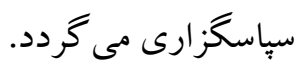

\section{References}

Abdi A, Moradi AR \& Akrmyan F.(2009). A comparison of the performance of people with post-traumatic stress disorder caused by the war and the normal meaning in autobiographical memory.Journal of Clinical Psychology. First Year, Issue III, 6253. (InPersian)

Ahadi M, Moradi A \& Hosni J. (2014). Study of autobiographical memory in immigrant adolescents with postraumatic stress disorder (PTSD)Journal of thought and behavior, ninth period, 34. (In Persian)

Allen RJ, Schaefer A \& Falcon T. (2014). Recollecting positive and negative autobiographical memories disrupts working memory.Acta psychologica, 151, 237-243.

Buckley TC, Blanchard EB \& Neill WT. (2002). Information processing and PTSD: A review of the empirical literature. Clinical Psychology Review,20: 1041-1065.

Cohen JA, Issues T.W.G.O.Q \& AACAP Work Group on Quality Issues. (2010). Practice parameter for the assessment and treatment of children and adolescents with posttraumatic stress disorder. Journal of the American Academy of Child \& Adolescent Psychiatry, 49(4), 414-430.

Conway MA. (2005). Memory and the self. Joumal of memory and language. 53, pp.594-628.

Crane C, Heron J, Gunnell D, Lewis G, Evans J \& Williams JMG. (2014). Childhood traumatic events and adolescent overgeneral autobiographical memory: Findings in a UK cohort.Joumal of behavior therapy and experimental psychiatry,45(3): 330-338.

Dalgleish T, Williams JMG, Golden AMJ, Barnard PJ \& AuYeung C.(2007).Reduced specificity of autobiographical memory and depression: The role of executive processes.
در زنان افسرده بيش تر از خروه مضطرب و سالم است ولى بين زنان مضطرب و سالم تفاوتى ديده نشد.

جانبازان مبتلا به استرس يس از سانحه به دليل روبرو شدن با حوادث آسيب زاى زياد در دوران جنگ تحميلى، در كنترل كامل فرايندهاى جستوجو در حافظه با ناتوانى روبرو هستند. افراد مبتلا به استرس يس از سانحه به وسيله راهبردهاى شناختى كه براى كاهش اثرات تجربه آسيب زا به كار مى گيرند، در بازيابى از حافظه شرح حال كمتر اختصاصى عمل كرده و در ياسخ به تكليف خاطرات كلى ارائه مى دهند؛ بنابر اين، آموزش اختصاص سازى حافظه سر كذشتى در جانبازان با اختلال استرس يس از سانحه كه از مشكلات اعصاب و روان مرتبط با مواجهه با حوادث آسيب زا در رنج هستند، مى تواند در جهت كاهش نشانه هاى استرس يس از سانحه و ارتقاى سلامت روان آنان سازنده و مفيد باشد. از جمله محدوديت هاى اين يزوهش شامل: از آنجا كه طول مدت بيخيرى اثرات درمانى محدود (ا ماهه) بود لذا به نظر مىرسد كه ييكيرى در بلند مدت جهت بررسى تداوم اثرات درمانى ضرورى باشد .از ديخر محدوديت هاى اين يثزوهش در نحوه نمونه گيرى است كه بهصورت در دسترس بود.

\section{نتيجه كيرى}

با توجه به نقش حافظه سر گذشتى در ييشينى

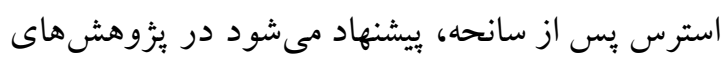
آتى اثر اختصاصى سازى حافظه بر ميزان عود بيماران بررسى شود؛ و نيز يزوهش هاى ديخرى با بيخيرى احساى طولانىمدت صورت كيرد. سياسگز ارى 
Joumal of Experimental Psychology. General.

Dalgleish T. (2004). Cognitive approaches to posttraumatic stress disorder. The evolution of multi-representational theorizing. Psychological Bulletin. 130, 228-260.

Delavare A. (2007). Research Methods in Psychology and Educational Sciences. Edit Publishing, 312(In Persian)

Diehl T \& Goldberg K. ( 2004). Psychiatric nursing.1th ed. Philadelphia. Lippincott; 110-101.24.

Goudarzi MA. (2003). Study of Traumatic Stress Scale validity and reliability of the Mississippi(scale).Joumal of Psychology, Seventh year, No 2, pp. 153-177. (In Persian)

Graham B, Herlihy J \& Brewin CR. (2014). Overgeneral memory in asylum seekers and refugees. Journal of behavior therapy and experimental psychiatry. 45(3), 375-380.

Hajmohammadi F \& Neshat doost HT. (2018). Comparison the specificity and over gencrality autobiographical memory in women with depression, anxiety and healthy.shenakht journal of psychology and psychiatry vol.4/No.4/winter, pp.44-56. (In Persian)

Jabson AF \& Okami SW. (2009). Autobiographical memory and trauma in adolescents. Jour-nal of Behavior Therapy and Experimental Psychiatry. 31, pp.29-39.

Leventon JS, Stevens JS \& Bauer PJ. (2014). Development in the neurophysiology of emotion processing and memory in schoolage children.Developmental cognitive neuroscience.

Moein Farsani R \& Ranjbar Kohan Z. (2017). The Effectiveness of Autobiographical Memory Specificity Training(MEST) on Depression inVeterans with Post-Traumatic Stress Disorder in Isfahan. Joumal of Military Medicine,Volume 19(1), 40-48. (In Persian)

Momartin S, Silove D, Manicavasagar V \& Steel Z. (2004). Comorbidity of PTSD and depression: associations with trauma exposure, symptom severity and functional impairment in Bosnian refugees resettled in Australia. Joumal of affective disorders, 80(2-3), 231-238.
Moradi A, Salimi M \& Fathi Ashtiani A. (2010). Memory function in patients with posttraumatic stress disorder caused by the war. Joumal of Behavioral Sciences.Volume 4, Number4, Issue 14, 276-269. (In Persian)

Moradi ER, Rahimi movakhar V, Myraqayy AM, Parhon H \& Mirzaie j. (2013). Autobiographical memory retrieval, evaluation and definition of trauma in people with post-traumatic stress disorder. Joumal of Psychology 67, seventeenth year, No 3,259-242. (In Persian)

Nelson KD \& Fivush R. (2004). The emergence of autobiographical memory:A social cultural development theory. Psychological Review. 111,486-511.

Raes F, Williams JM \& Hermans D. (2009). Reducing cognitive vulnerability to depression:a preliminary investigation of Memory Specificity Training (MEST) in inpatients with depressive symptomatology. J Behav Ther Exp Psychiatry. 40(1): pp. 24 38.

Saadat S, Javadi M, Divshali BS, Tavakoli AH, Ghodsi SM, Montazeri A \& RahimiMovaghar V. (2010). Health-related quality of life among individuals with long-standing spinal cord injury: a comparative study of veterans and non-veterans. BMC Public Health, 10(1), 6. (In Persian)

Sadock B \& Ruiz P. ( 2015). Kaplan \& Sadock's synopsis of psychiatry: behavioral sciences. Walters Kluwer.

Sutherland K \& Bryant RA. (2007). Autobiographical memory in postraumatic stress disorder before and after treatment. Behaviour Research and Therapy. 45(12), 2915-2923.

Weathers FW, Litz BT, Herman DS, Huska JA \& Keane T. (1993). The PTSD cheklist (PCL).Reliability. Validity \& diagnostic utility. Presented at the 9 Th Annual Meeting of the Inemational Society for Traumatic Seress Hissre Studies,October, Sam Antunio, TX.

Williams JMG, Barnhofer T, Crane C, Hermans D, Raes F, Watkins E \& Dalgleish T. (2007). Autobiographical memory specificity and emotional disorder.Psychological Bulletin. pp. 133-148. 